\title{
DISTRIBUTION AND DYNAMIC OF CASTOR FIBER (CASTORIDAE, MAMMALIA) POPULATION IN FOREST-STEPPE RIVERS: A CASE OF THE STATE NATURE RESERVE PRIVOLZHSKAYA LESOSTEP', PENZA REGION, EUROPEAN RUSSIA
}

\author{
Ivan V. Bashinskiy ${ }^{1}$, Vitaly V. Osipov ${ }^{2}$ \\ ${ }^{1} A . N$. Severtsov Institute of Ecology and Evolution of RAS, Russia \\ e-mail:ivbash@mail.ru \\ ${ }^{2}$ State Nature Reserve Privolzhskaya Lesostep', Russia \\ e-mail:osipovv@mail.ru
}

Received: 23.04 .2018

\begin{abstract}
The work presents the first results of annual monitoring of a beaver population on the territory of Ostrovtsovskaya Lesostep' (State Nature Reserve Privolzhskaya Lesostep', Penza region). In 2014-2017 all water-courses and water-bodies, including the River Khoper, River Selimutka, River Yuzhnaya and several oxbows of the Khoper were investigated twice a year for assessing the beaver abundance using the method of settlements capacity. The mean density of dams was $7.7 \mathrm{dams} / \mathrm{km}$ of watercourse, the maximum was on the River Yuzhnaya -10.8 dams $/ \mathrm{km}$, and the minimum was on the River Selimutka $-5.5 \mathrm{dams} / \mathrm{km}$. During the study period 10 to 13 beaver settlements were observed, the total abundance of beavers tends to decrease (from 42 to 30 animals). The present density of beavers and a lack of food resources limit a further increase of the species abundance.
\end{abstract}

Key words: ecosystem monitoring, Eurasian beaver, Protected Area, small rivers

\section{Introduction}

In the middle of the last century, the wide reintroduction of the beaver (Castor fiber Linnaeus, 1758) was carried out (Zharkov \& Sokolov, 1967). Nowadays the species occupies vast territories from forest-tundra to forest-steppe (Halley et al., 2012). Changes of ecosystems have led to the situation that beavers face a lack of suitable habitats, especially at the borders of its area. Beaver population dynamics were studied for a long time (since 1940-1950s in some territories), but mainly in forest landscapes (Petrosyan et al., 2016). Foreststeppe and steppe territories became inhabited by beavers in recent times, so there are not enough data for analysis of the beaver abundance dynamics. Among European countries and countries inhabited by beavers, the Russian Federation has the maximum areas of steppe and forest-steppe landscapes (Fig. 1).

The data of the State Hunter Agency (Borisov \& Baranov, 2018) show a tendency of beaver number growth in forest-steppe regions (Fig. 1). Especially such situations could be found in Penza (where our study has been carried out), Voronezh, Kursk, Ulyanovsk and Belgorod regions. But the beaver number at the border of the area on the steppe territories stayed stable or slightly decreased (e.g. Samara, Orenburg, Volgograd,
Rostov regions) (Fig. 1). The last decades these regions began attract attention of beaver scientists. For example, in Samara region the consequences of beaver reintroduction and population dynamics (Brozdnyakov, 2005), and the influence of beaver foraging activity on woody vegetation (Brozdnyakov \& Shestun, 2005; Antipov, 2012) were studied. In Orenburg region, the beaver population dynamics and the beaver impact on steppe rivers were observed (Tyutina, 2010; Ustabayeva, 2013). However, these data of beaver abundance were analysed on a wide regional scale, without minding landscape conditions. The same approach for beaver monitoring was used in Kursk (Rusanov, 2015) and Rostov regions (Stakheev et al., 2018). Also, for example, in the forest-steppe Tambov region, beavers were studied mainly in valleys of large rivers, which are covered by floodplain forests (Emelyanov et al., 2008; Kireev \& Emelyanov, 2014).

Thus, most of the studies mentioned above were carried out in woody valleys of large rivers under similar conditions with forest territories, and special monitoring in steppe and forest-steppe valleys was missed. Just Orenburg works were dedicated to steppe landscapes, but that described the local situation (one small stream) and had a small duration of observations. 


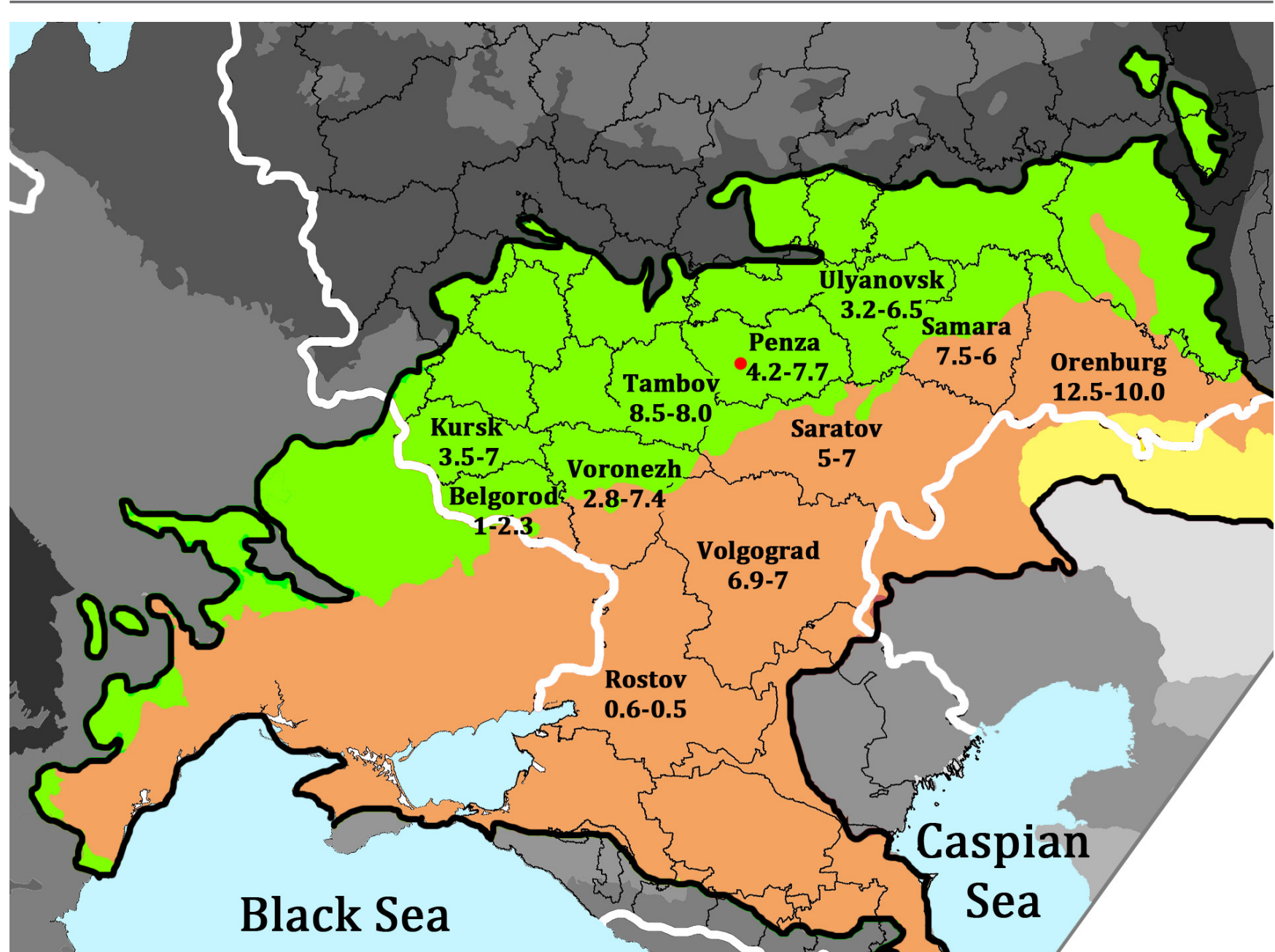

Fig. 1. Russian regions on the map of terrestrial ecoregions of the world (Olson et al., 2001). Black line outlines European steppe ecoregions: East European forest-steppe (light green), Pontic steppe (orange) and Kazakh steppe (yellow). Numbers show changes in beaver population from 2008 to 2013 ( $\times$ thousands animals) in regions near southern border of beavers area (Borisov \& Baranov, 2018). White line - border of the Russian Federation. Red dot - Ostrovtsovskaya Lesostep'.

A growth of the beaver population also was observed in neighbouring countries, for example in Kazakhstan. But that country has very extreme conditions for beavers, because of an almost total absence of trees and some water salinity (Baytanaev et al., 2010, 2011). Also, beavers intensively inhabit Ukraine's forest-steppe (Antonets, 2009; Volokh, 2011; Tokarsky et al., 2012). There are many studies that concern the population and habitat preferences of beavers on the southern border of the area, e.g. in Romania (Pașca et al., 2013), Slovakia and Hungary (Čanády et al., 2016), Bosnia and Herzegovina (Trbojevic \& Trbojevic, 2016). But the present population growth occurs in forest landscapes and valleys of large rivers, and small streams stay out of attention.

Also, we should note the studies conducted in North America about beaver population in prairies and in the middle southern states of USA (e.g. Swenson et al., 1983; Naiman et al., 1988; Dieter \& McCabe, 1989; Busher \& Lyons, 1999; Hood \& Bayley, 2008). But they concern Castor canaden- sis Kuhl, 1820 and the environmental conditions and situation differ much from European Russia.

The location of the Penza region in the middle of the forest-steppe ecoregion made it a suitable model territory for studying beaver population and dynamics in such landscapes and valleys. The territory of the state nature reserve is very useful for a longtime annual monitoring of beavers.

On the territory of Ostrovtsovskaya Lesotep' (cluster of the State Nature Reserve Privolzhskaya Lesostep') the presence of beavers was documented from 2004 (Dobrolyubov, 2012). The first data about the beaver abundance on this territory was received in 2013 (Bashinskiy \& Osipov, 2016). Since 2014 we have done an annual monitoring of the beaver population, and its first results are presented in this paper.

\section{Material and Methods}

The study was carried out in 2014-2017 on the territory and vicinity of the Ostrovtsovskaya Lesostep', part of the State Nature Reserve Privolzhskaya Leso- 


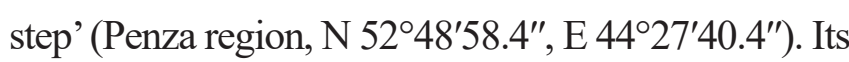
area is $3.52 \mathrm{~km}^{2}$. And its length from east to west is 3.9 $\mathrm{km}$, from south to north $-2.2 \mathrm{~km}$. It occupies the large ravine and part of a watershed that was formed by cover loams of the moraine of the Dnepr glaciation. The main feature of watershed plain is its high alteration by anthropogenic processes - total plowing, deforestation, erosion, construction and exploitation of roads, grazing, fires and other (Nevorotov \& Novikova, 2012). There are two rivers on the territory - Selimutka and Yuzhnaya, which interflow near the southern border of the reserve and then fall into the River Khoper on the eastern border. The total length of the streams of the Ostrovtsovskaya Lesostep' is $7.8 \mathrm{~km}$.

The steppe and meadow vegetation occupies $52.2 \%$ of the territory. The woody vegetation covers $47.8 \%$ of its area and is presented by Prunus spinosa L. (14.2\%), P. fruticosa Pall. (6.1\%), Acer tataricum L. (5.8\%), Padus avium L. (5.6\%), Alnus glutinosa (L.) Gaertn. (3.9\%), Salix fragilis L. (2.4\%), Populus tremula L. (2.2\%), Prunus tenella Batsch (2.1\%), Rhamnus sp. (1.4\%), Spiraea crenata L. (1.3\%), Salix cinerea L. (1.1\%) and Cytisus ruthenicus Wol. (0.6\%) (Kudryavtsev, 2012).

We investigated all water courses and water bodies, including the River Khoper (width $-5-10$ $\mathrm{m}$, studied length $-1 \mathrm{~km}$, depth $-0.5-2.0 \mathrm{~m})$, River Selimutka (width $-1-2 \mathrm{~m}$, length $-6.52 \mathrm{~km}$, depth $-0.3-0.5 \mathrm{~m}$ ) and River Yuzhnaya (width $-1 \mathrm{~m}$, length $-3.14 \mathrm{~km}$, depth $-0.1-0.3 \mathrm{~m}$ ) and several forest and open oxbows (mean area varies from 753 to $4572 \mathrm{~m}^{2}$, depth $-1.5-2 \mathrm{~m}$ ) of the River Khoper.

To conduct the monitoring of the beaver population we used methods of Borisov (1986) and Dyakov (1975). Using GPS we mapped all evidences of beaver activities (dams, traces, trails, marks), that allow us to determine borders of beaver settlements, their condition (used and abandoned) and capacity (single animal, pair, family with young-of-years, large family), and estimate number of beavers.

We measured the sizes of beaver ponds (with GPS Garmin 60Cx), beaver dams (with tape-measure) and water depth (with tape-measure); on streams we measured flow rates (with flow rate meter GMH 3330) and counted water discharge (product of flow velocity and cross-section area).

\section{Results and Discussion}

During the study period we observed 10 to 13 beaver settlements, the assessed abundance is shown in Table.

The studied territory had a high density of beavers. We found 78 dams (both active and demol- ished) (Fig. 2). Beavers made 36 dams on the River Selimutka and 42 on the River Yuzhnaya with its tributary. The mean density of dams was 7.7 dams/ $\mathrm{km}$ of a watercourse, the maximum was on the River Yuzhnaya - 10.8 dams $/ \mathrm{km}$, and the minimum was on the River Selimutka - 5.5 dams $/ \mathrm{km}$. These parameters are lower than those in forest regions with a long history of beaver impact. For example, in the Prioksko-Terrasny Nature Reserve - beaver settlements are known here since 1948 - the density of dams on streams was $10 \mathrm{dams} / \mathrm{km}$ to $22 \mathrm{dams} / \mathrm{km}$ (Albov et al., 2012). But in some forest regions with a lack of food resources and unstable beaver settlements, the density of dams could be similar to our results - 4.4-6.7 dams/km, e.g. in the Rdeysky State Nature Reserve (Zavyalov \& Letsko, 2006).

$25-30 \%$ of the settlements were inhabited by single animals or young pairs. During the period of monitoring only one large stable settlement was observed. It was situated in the upper flow of the River Selimutka (Fig. 2). This part of the valley had a forest vegetation with domination of preferable trees (Populus tremula, Salix sp.), while Alnus glutinosa mainly prevailed along the other part of the floodplain. Also, the low flow rates $(0.08 \mathrm{~m} / \mathrm{s})$ were benefited for pond stability in the upper part of the river. In this settlement the beaver pond was the largest in the studied territory, its square was about $100000 \mathrm{~m}^{2}$, length of the dam was more than $300 \mathrm{~m}$, the height of the dam was about $1 \mathrm{~m}$.

Besides, a large beaver family inhabited the central part of the River Yuzhnaya. Poor food resources caused that the beaver family changed the location of their settlements regularly. A weak water discharge of undammed streams $\left(0.001 \mathrm{~m}^{3} / \mathrm{s}\right)$ necessitated the beavers to construct cascades of dams to accumulate enough amounts of water. Also, it prevented ponds from drainage of spring floods, so all beaver structures (dams, canals, burrows) could exist for years without maintaining. Beaver ponds of the River Yuzhnaya were usually small (about 1400-2000 m², length of dams usually was $10 \mathrm{~m}$ ). But the largest pond was about $22000 \mathrm{~m}^{2}$, with a dam about $70 \mathrm{~m}$ long and heights about $1 \mathrm{~m}$.

Table. Number of beavers (individuals/families) in Ostrovtsovskaya Lesostep'

\begin{tabular}{|l|c|c|c|c|}
\hline \multirow{2}{*}{\multicolumn{1}{c|}{ Water bodies }} & \multicolumn{4}{c|}{ Years } \\
\cline { 2 - 5 } & 2014 & 2015 & 2016 & 2017 \\
\hline River Khoper & $4 / 1$ & $4 / 1$ & $4 / 1$ & $4 / 1$ \\
\hline River Selimutka & $16 / 5$ & $12 / 4$ & $8 / 3$ & $12 / 4$ \\
\hline River Yuzhnaya and its tributaries & $12 / 4$ & $12 / 4$ & $14 / 5$ & $10 / 4$ \\
\hline Oxbows & $10 / 3$ & $8 / 3$ & $6 / 2$ & $4 / 2$ \\
\hline Total & $42 / 13$ & $36 / 12$ & $32 / 11$ & $30 / 11$ \\
\hline
\end{tabular}




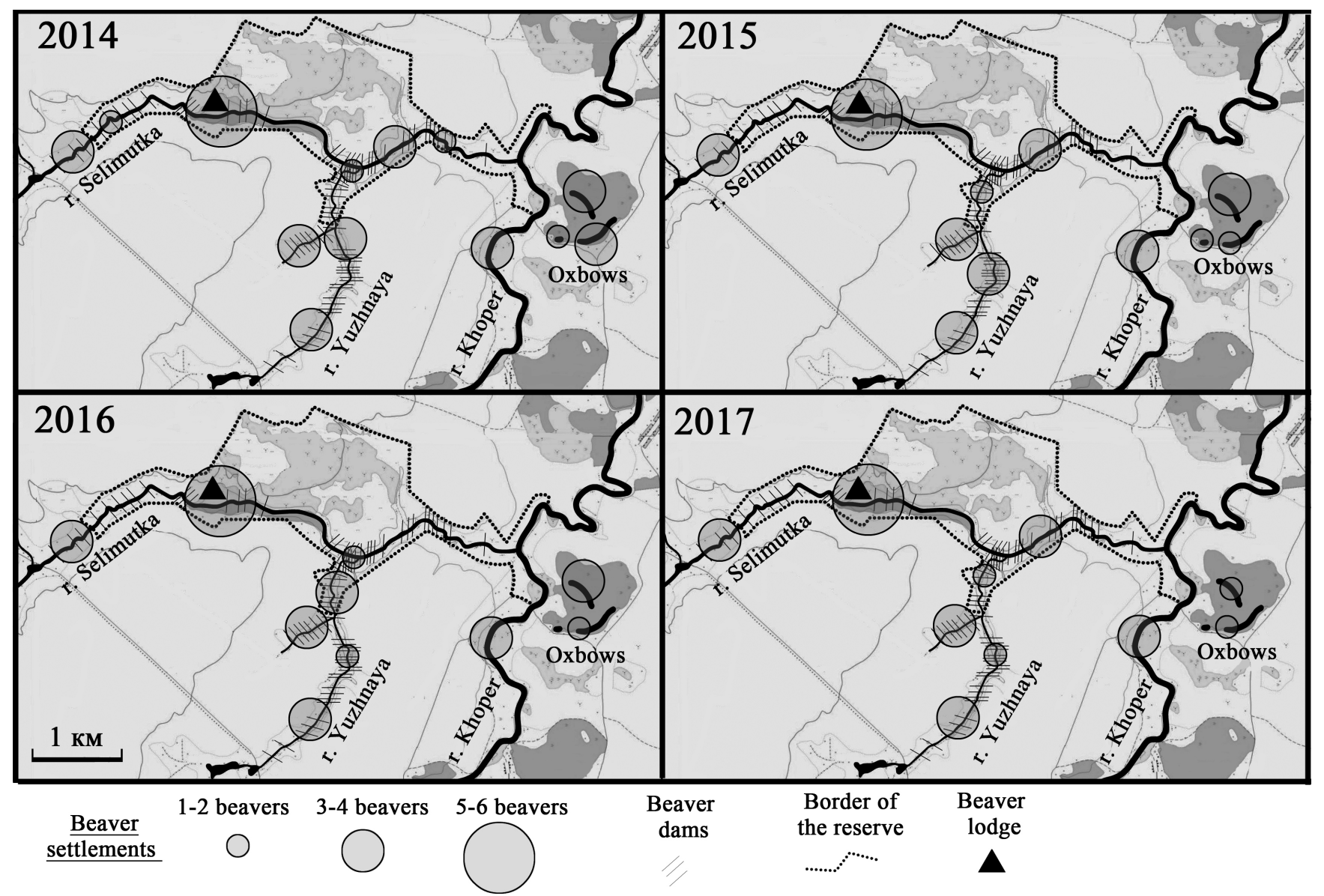

Fig. 2. Distribution of beaver settlements, dams and lodges in Ostrovtsovskaya Lesostep' in 2014-2017 (woody vegetation is shown in dark grey).

The middle and low parts of the River Selimutka were not suitable enough for beavers. The beaver activity was limited by high flow rates $(0.44$ $1.18 \mathrm{~m} / \mathrm{s})$, narrow floodplain $(5-10 \mathrm{~m})$, steep and high slopes. So all ponds had channel-like form, with a width of 2-3 m and length of about $50 \mathrm{~m}$. Annual spring floods destroyed dams. So beavers left the settlements after wintering. Usually this part of the river was inhabited by single beavers or young couples who came from the River Khoper, where large families lived.

Also, beavers inhabited oxbows on the area adjacent to the Ostrovtsovskaya Lesostep'. Those water bodies were presented by two types - forest and open. Open oxbows were exposed to intense drying during summer (surface areas could decrease more than 2.0-2.5 times), so they were used by single animals and couples. The forest oxbows were more stable, so we observed two families there. Beavers made channels and small dams (width 1.0-1.5 m, height 0.7-1.0 m) between oxbows to prevent melting water drainage during spring. At the end of 2016 the beaver number decreased noticeably in oxbows, so we suggest some anthropogenic impact because that territory was situated outside the nature reserve and was used for hunting.

The beaver habitats of Ostrovtsovskaya Lesostep' could be divided in five groups - streams and its parts without beaver activity, young beaver ponds, old beaver ponds, abandoned beaver ponds and standing water bodies. Undammed streams could be visited by beavers, but they use it for feeding, and do not create ponds. The main reasons of beaver absence in some parts of the valley are poor food resources and steep slopes. Young beaver ponds are newly built ponds or those which exist for 1-2 years before spring floods demolish them. Old beaver ponds are water-bodies that were created more than three years ago. Usually they were formed in cascades that prevent them from demolishing during spring floods. Abandoned ponds appear when beavers leave the territory, and dams are destroyed. They are quite similar to undammed streams, but have some remains of beaver activities - mounds, channels, dams, backwaters. Standing water bodies near Ostrovtsovskaya Lesostep' are presented by oxbows which also are used by beavers. Beavers create channels and small dams between oxbows, and also clutter up the water by wood and feces. 
The territory of Ostrovtsovskaya Lesostep' had a lack of food resources and unsuitable relief of river valleys, so the present density of the beaver population limits a further growth of the species' abundance. There are some undammed small streams (tributaries of the River Selimutka and the River Yuzhanaya), which could potentially be inhabited by beavers. There are no beaver predators in the territory of the reserve and surroundings (Dobrolyubov, 2012), so this factor could not influence the population dynamic. But the vicinity of Ostrovtsovskaya Lesostep' is used for hunting, hence some beavers could be killed by men. So probably anthropogenic press on nearby territories and increasing beaver attraction for hunters could lead to a decline of the beaver number in Ostrovtsovskaya Lesostep'.

\section{Acknowledgements}

The authors are grateful to Alexander N. Dobrolyubov (Director of the State Nature Reserve Privolzhskaya Lesostep', Russia) for support of the field surveys. This study was funded by the Russian Foundation for Basic Research (grant number 15-29-02550).

\section{References}

Albov S.A., Andreeva M.V., Bashinskiy I.V., Golubkov V.V., Katsman E.A., Goriaynova Z.I., Krylov A.V., Onipchenko V.G., Prokin A.A., Khlyap L.A. 2012. European beaver (Castor fiber L.) as a key species of a small river ecosystem (Prioksko-Terrasny Nature Biosphere Reserve). Moscow: KMK Scientific Press Ltd. 150 p. [In Russian]

Antipov V.V. 2012. Influence food supply activity of beaver (Castor fiber L.) on water-front forest in the foreststeppe and stepp zones on the example of the Samara and Orenburg regions. Proceedings of Samara Scientific Centre RAS 14(1-1): 181-185. [In Russian]

Antonets N.V. 2009. Modern state of the beaver population in Dnipropetrovsk region. In: Biodiversity and the role of animals in ecosystems: Materials of the V International Scientific Conference. Dnipropetrovsk: Lira. P. 316-317. [In Russian]

Bashinskiy I.V., Osipov V.V. 2016. Beavers in Russian forest-steppe - characteristics of ponds and their impact on fishes and amphibians. Russian Journal of Theriology 15(1): 34-42. DOI: 10.15298/rusjtheriol.15.1.06

Baytanaev O.A., Cherepanov A.P., Savinkov R.V., Goncharov M.V., Bogoley O.B. 2010. European beaver (Castor fiber L., 1758) in Eastern Kazakhstan. Bulletin of $\mathrm{Ka}$ $z N U$. Biology series 2(44): 72-75. [In Russian]

Baytanaev O.A., Gogel A.A., Zhadrasinov R.A., Abayev O.J. 2011. European beaver (Castor fiber L., 1758) in Aktyubinsk region. Experimental Biology 47(1): 62-65. [In Russian]

Borisov B.P. 1986. Methodic guidance for counting beaver number on large territories. Moscow: VNIL Glavokhoty RSFSR. 20 p. [In Russian]
Borisov B.P., Baranov V.N. 2018. European Beaver. In: Status of hunting resources in the Russian Federation in 2008 2013. FGBU Centrokhotcontrol. Available from http:// www.ohotcontrol.ru/resource/Resources 2008-2013/ Resources_2008-2013.php [In Russian]

Brozdnyakov V.V. 2005. The forming of beavers population (Castor fiber L.) in Samara region and evaluation of trophic factor effect. Vestnik SamGU - Natural science series 2(36): 222-230. [In Russian]

Brozdnyakov V.V., Shestun K.V. 2005. Impact of foraging factor on beaver (Castor fiber) population of Samara region. Bulletin Samarskaya Luka 16: 214-226. [In Russian]

Busher P.E., Lyons P.J. 1999. Long-Term Population Dynamics of The North American Beaver Castor Canadensis on Quabbin Reservation, Massachusetts, and Sagehen Creek, California. In: P.E. Busher, R.M. Dzięciołowski (Eds.): Beaver Protection, Management, and Utilization in Europe and North America. Boston: Springer. P. 147-160. DOI: 10.1007/978-1-4615-4781-5 16

Čanády A., Krišovský P., Bajomi B., Huber A., Czabán D., Olekšák M. 2016. Is new spread of the European beaver in Pannonian basin an evidence of the species recovery? European Journal of Ecology 2(2): 44-63. DOI: 10.1515/eje-2016-0015

Dieter C., McCabe T. 1989. Factors Influencing Beaver Lodge-site Selection on a Prairie River. American Midland Naturalist 122(2): 408-411. DOI: 10.2307/2425928

Dobrolyubov A.N. 2012. Fauna of mammals of Ostrovtsovskaya Lesostep'. Proceedings of the State Nature Reserve Privolzhskaya Lesostep' 2: 245-247. [In Russian]

Dyakov Y.V. 1975. Beavers of European part of Soviet Union. Moscow: Moskovskiy rabochiy. 480 p. [In Russian]

Emelyanov A.V., Kireev A.A., Starkov K.A., Zotov D.A., Bakumenko D.V., Chernova N.A. 2008. Results of studying of beaver population in the national park «Voroninsky» and adjoining territories. Tambov University Reports. Series: Natural and Technical Sciences 13(4): 295-300. [In Russian]

Halley D.J., Rossel F., Saveljev A.P. 2012. Population and Distribution of Eurasian Beaver. Baltic Forestry 18(1): 168-175.

Hood G.A., Bayley S.E. 2008. Beaver (Castor canadensis) mitigate the effects of climate on the area of open water in boreal wetlands in western Canada. Biological Conservation 141(2): 556-567. DOI: 10.1016/j.biocon.2007.12.003

Kireev A.A., Emelyanov A.V. 2014. Analysis of quality of beaver settlements bed type in forest-steppe zone. Tambov University Reports. Series: Natural and Technical Sciences 19(1): 275-280. [In Russian]

Kudryavtsev A.Y. 2012. Dynamic of arboreous and fruticous communities of Ostrovtsovskaya Lesostep'. Proceedings of the State Nature Reserve Privolzhskaya Lesostep' 2: 140-158. [In Russian]

Naiman R.J., Johnston C.A., Kelley J.C. 1988. Alteration of North American Streams by Beaver. BioScience 38(11): 753-762. DOI: $10.2307 / 1310784$

Nevorotov A.I., Novikova L.A. 2012. Physico-geographical conditions of Ostrovtsovksaya Lesostep'. Proceedings of the State Nature Reserve Privolzhskaya Lesostep' 2: 7-10. [In Russian] 
Olson D.M., Dinerstein E., Wikramanayake E.D., Burgess N.D., Powell G.V.N., Underwood E.C., D'Amico J.A., Itoua I., Strand H.E., Morrison J.C., Loucks C.J., Allnutt T.F., Ricketts T.H., Kura Y., Lamoreux J.F., Wettengel W.W., Hedao P., Kassem K.R. 2001. Terrestrial ecoregions of the world: a new map of life on Earth. Bioscience 51(11): 933-938. DOI: 10.1641/0006-3568(2001)051[0933:TE OTWA]2.0.CO;2

Pașca C., Ionescu G., Sârbu G., Vișan D. 2013. Evaluation of habitats and estimation of population number of beaver (Castor fiber) in Romania. Revista de Silvicultură și Cinegetică 18(33): 121-125.

Petrosyan V.G., Golubkov V.V., Zavyalov N.A., Goryainova Z.I., Dergunova N.N., Omelchenko A.V., Bessonov S.A., Albov S.A., Marchenko N.F., Khlyap L.A. 2016. Patterns of population dynamics of Eurasian beaver (Castor fiber L.) after reintroduction into nature reserves of the European part of Russia. Russian Journal of Biological Invasions 7(4): 355-373. DOI: 10.1134/S2075111716040068

Rusanov N.V. 2015. Population dynamic of beavers (Castor fiber L.) of Kursk region and its impact on ecology. In: Biological diversity as the basis for the existence and functioning of natural and artificial ecosystems. Voronezh: Istoki. P. 125-128. [In Russian]

Stakheev V.V., Shmatko V.Y., Panasyuk N.V., Kleshchenkov A.V. 2018. Current status of population and ecological peculiarities of the eurasian beaver Castor fiber L. in Rostov region. South of Russia: Ecology, Development 13(2): 196-202. DOI: 10.18470/1992-1098-2018-2-196-202

Swenson J., Knapp S., Martin P., Hinz T. 1983. Reliability of Aerial Cache Surveys to Monitor Beaver Population Trends on Prairie Rivers in Montana. Journal of Wildlife Management 47(3): 697-703. DOI: 10.2307/3808605
Tokarsky V.A., Volokh A.M., Tokarskaya N.V., Skorobogatov Y.V. 2012. Renewal of beaver (Castor fiber L.) population in Left-Bank Ukraine. Journal of V.N. Karazin Kharkiv National University. Series: Biology 16(1035): 114-124. [In Russian]

Trbojevic I., Trbojevic T. 2016. Distribution and population growth of Eurasian beaver (Castor fiber Linnaeus, 1758) in Bosnia and Herzegovina 10 years after reintroduction. Glasnik Šumarskog fakulteta Univerziteta u Banjoj Luci 25: 51-60. DOI: 10.7251/ GSF1625051T

Tyutina Y.V. 2010. Beavers (Castor fiber) spreading and their impact on the hydro-ecosystems of the national park «Orenburgsky». Izvestia of the state Orenburg agrarian university 1 (25-1): 180-182. [In Russian]

Ustabayeva Y.V. 2013. Regional ecological features of beaver population and its impact on steppe biogeocoenoses of Orenburg region. PhD Thesis. Moscow. 124 p. [In Russian]

Volokh A.M. 2011. Beaver introduction in southern regions of Ukraine. In: IX Meeting of Theriological Society of $R A S$ «Theriofauna of Russian Federation and neighboring territories». Moscow: KMK Scientific Press Ltd. P. 102. [In Russian]

Zavyalov N.A., Letsko I.V. 2006. The European beaver (Castor fiber L.) in Rdeysky Reserve and in adjacent territories (NW Russia). In: Abstracts of $4^{\text {th }}$ European Beaver Symposium / $3^{\text {rd }}$ Euro-American Beaver Congress (Freising, Germany). Freising, Germany. P. 70.

Zharkov I.V., Sokolov V.Y. 1967. European beaver (Castor fiber Linnaeus, 1758) in the USSR. Acta Theriologica 12(3): 27-46. DOI: 10.4098/AT.arch.67-3

\title{
РАСПРЕДЕЛЕНИЕ И ДИНАМИКА ПОПУЛЯЦИИ CASTOR FIBER (CASTORIDAE, МАММАLIA) В ДОЛИНАХ ЛЕСОСТЕПНЫХ РЕК: НА ПРИМЕРЕ ЗАПОВЕДНИКА «ПРИВОЛЖСКАЯ ЛЕСОСТЕПЬ» (ПЕНЗЕНСКАЯ ОБЛАСТЬ, ЕВРОПЕЙСКАЯ РОССИЯ)
}

\author{
И. В. Башинский ${ }^{1}$ В. В. Осипов ${ }^{2}$ \\ ${ }^{1}$ Институт проблем экологии и эволюиии имени А.Н. Севериова РАН, Россия \\ e-mail:ivbash@mail.ru \\ ${ }^{2}$ Государственный природный заповедник «Приволжская лесостепь», Россия \\ e-mail: osipovv@mail.ru
}

В работе представлены первые результаты ежегодного мониторинга популяции бобров на территории Островцовской лесостепи (Государственный природный заповедник Приволжская лесостепь). В 2014-2017 годах были обследованы все водотоки и водоемы, в том числе р. Хопер, р. Селимутка, р. Южная и несколько стариц. Учеты бобров проводили дважды в год с использованием метода оценки мощности поселения. Средння плотность плотин составлял 7.7 дамб на 1 км русла, максимальная наблюдалась р. Южная - 10.8, и минимальная на р. Селимутка - 5.5. За весь период наблюдалось от 10 до 13 бобровых поселений, общая численность бобров имела тенденцию к снижению (с 42 до 30 животных). Современная плотность бобров и недостаток кормовых ресурсов лимитирует дальнейшее увеличение численности вида.

Ключевые слова: малые реки, обыкновенный бобр, особо охраняемая природная территория, экосистемный мониторинг 